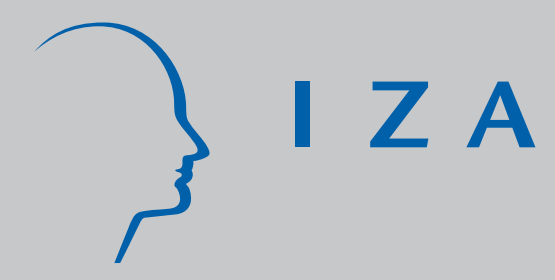

IZA DP No. 3887

Trade Openness and the Demand for Skills:

Evidence from Turkish Microdata

Elena Meschi

Erol Taymaz

Marco Vivarelli

December 2008 


\title{
Trade Openness and the Demand for Skills: Evidence from Turkish Microdata
}

\author{
Elena Meschi \\ Institute of Education, University of London \\ and CSGR, Warwick University \\ Erol Taymaz \\ Middle East Technical University \\ Marco Vivarelli \\ Università Cattolica del Sacro Cuore, Milan, \\ Max Planck Institute of Economics, Jena, \\ CSGR, Warwick University and IZA
}

\section{Discussion Paper No. 3887 \\ December 2008}

\author{
IZA \\ P.O. Box 7240 \\ 53072 Bonn \\ Germany \\ Phone: +49-228-3894-0 \\ Fax: +49-228-3894-180 \\ E-mail: iza@iza.org
}

\begin{abstract}
Any opinions expressed here are those of the author(s) and not those of IZA. Research published in this series may include views on policy, but the institute itself takes no institutional policy positions.

The Institute for the Study of Labor (IZA) in Bonn is a local and virtual international research center and a place of communication between science, politics and business. IZA is an independent nonprofit organization supported by Deutsche Post World Net. The center is associated with the University of Bonn and offers a stimulating research environment through its international network, workshops and conferences, data service, project support, research visits and doctoral program. IZA engages in (i) original and internationally competitive research in all fields of labor economics, (ii) development of policy concepts, and (iii) dissemination of research results and concepts to the interested public.
\end{abstract}

IZA Discussion Papers often represent preliminary work and are circulated to encourage discussion. Citation of such a paper should account for its provisional character. A revised version may be available directly from the author. 


\section{ABSTRACT \\ Trade Openness and the Demand for Skills: Evidence from Turkish Microdata}

In this paper we report evidence on the relationship between trade openness, technology adoption and relative demand for skilled labour in the Turkish manufacturing sector, using firm-level data over the period 1980-2001. In a dynamic panel data setting using a unique database of 17,462 firms, we estimate an augmented cost share equation whereby the wage bill share of skilled workers in a given firm is related to international exposure and technology adoption. Overall, results suggest that trade openness and technology play a key role in shifting the demand for labour towards more skilled workers within each firm. Technologyrelated variables (domestic R\&D expenditures and technological transfer from abroad) are positive and significantly related to skill upgrading, as are the involvement of foreign capital in a firm's ownership and the propensity to export. Moreover, firms belonging to those sectors that most raised their imported inputs also experienced a higher increase in the labour cost share of skilled workers. This finding is consistent with the idea that imports by a middleincome country imply a transfer of new technologies that are more skill-intensive than those previously in use in domestic markets. This idea is reinforced by the finding that only imported inputs from industrialised countries - where the potential for innovation diffusion comes from - enter the estimated regression significantly.

JEL Classification: F16, O15, O33

Keywords: globalisation, skills, skill-biased technological change, technology transfer, GMM-SYS

Corresponding author:

Marco Vivarelli

Facoltà di Economia

Università Cattolica

Via Emilia Parmense 84

I-29100 Piacenza

Italy

E-mail: marco.vivarelli@unicatt.it 


\section{Introduction}

This paper examines the relationship between trade openness, technology adoption and the relative demand for skilled labour in Turkish manufacturing firms.

Turkey started a marked process of liberalisation in the early '80s and the volumes of exports and imports have continued to grow since then, making Turkish economy increasingly connected to the world market. This increasing trade openness has affected in particular the manufacturing sector, in which most of the growth of import and export has occurred. An important aspect of this process could be its impact on labour demand, and, more specifically, its impact on the relative demand for skilled labour. Indeed, over the same period, the relative demand for skilled labour increased substantially, leading to higher wage-gaps between skilled and unskilled workers. Whether these two simultaneous phenomena are linked has not been established yet.

Theoretical economic literature offers different predictions about the impact of trade liberalisation on labour demand in a developing country (DC). On the one hand, according to the central tenet of traditional trade theory - expressed in the HeckscherOhlin's theorem and in its Stolper-Samuelson corollary (HOSS hereafter) - we may expect a relative decrease in the demand for skilled labour. Indeed, openness should benefit a country's relatively abundant factor, because trade specialisation should favour sectors intensive in the abundant factor. Therefore, in the case of Turkey, which is abundant in unskilled labour relatively to the EU, its main trading partner, trade openness should have increased the demand for unskilled workers and raised their relative wages. On the other hand, if the HOSS assumption of homogeneous production functions ${ }^{1}$ among countries is relaxed, then international openness may facilitate technology diffusion from developed countries. Imports, exports and foreign direct investment (FDI) may act as a channel of technological upgrading and shift the production function towards more skill-intensive technologies. In other words, trade and FDI may induce and foster skill-biased technological change (SBTC).

This paper contributes to the debate presenting new empirical evidence. We estimate the impact of trade openness on labour demand by using a unique detailed panel of Turkish manufacturing firms (Annual Manufacturing Industry Statistics). The dataset,

\footnotetext{
${ }^{1}$ That is, the same technology and absence of scale economies.
} 
by covering all manufacturing firms employing 10 or more people, represents about $90 \%$ of (formal sector) manufacturing output over the 1980-2001 period, and it is therefore particularly well-suited to quantify the possible impact of firms' international exposure on the labour demand for skilled workers.

We think that Turkey is a particularly interesting setting to study the relationship between trade openness, technology adoption and the relative demand for skilled labour. In fact, Turkey is a middle-income country with sizeable commercial flows with developed countries, especially the EU⿱2${ }^{2}$. This makes it a net technology importer, and hence the ideal country for investigating the impact of potential imported SBTC. Indeed, trade openness is supposed to have a greater inequality-enhancing impact in middle-income countries, where "social capabilities" (Abramovitz, 1986) and “absorptive capacity” (Lall, 2004) are higher and where technology adoption from more advanced countries effectively acts as a channel for technological upgrading, thus leading to the increase in the relative demand for and wages of skilled workers.

From a policy perspective, Turkey presents an illustrative example for investigating the social impact of trade liberalisation policies: during the '80s, Turkey has carried out a significant trade liberalisation programme, shifting from a protectionist model characterized by heavy state intervention to a more outward-looking one.

The remainder of this paper is organised as follows: the next section reviews the theoretical and empirical literature on the interaction between trade openness, technological change and the relative demand for skilled labour, mainly focusing on developing countries. Section 3 introduces and describes the data. In Section 4 we discuss historical trends in the Turkish economy and present some descriptive statistics. In Section 5 we present the econometric analysis: first, we explain our empirical strategy (Section 5.1); then we present and discuss our results (Section 5.2). Finally, the last section proposes some concluding remarks.

\section{The literature}

The increase in the relative demand for skilled labour has been documented for many developed countries in the last three decades (see, among others, Katz and Murphy,

\footnotetext{
${ }^{2}$ From an EU policy perspective, Turkey is a country deserving investigation as it is the biggest and most populous EU candidate country.
} 
1992, for the US and Machin and Van Reenen, 1998 for other OECD countries). In the theoretical literature there is an ongoing debate about the relative importance of SBTC vs. international trade in explaining the observed widened wage differential between skilled and unskilled labour in the developed world (see Deardorff, 1998 for a comprehensive review of this debate). Although some authors have argued in favour of Stolper-Samuelson effects owing to increased trade (see for example, Leamer, 1994; Wood, 1994), most papers find that pervasive SBTC has been the main cause of the movements in relative wages and demand for skilled versus unskilled workers (see, for instance, Krugman and Lawrence, 1993; Berman, et al., 1994).

From a theoretical point of view, in the developed world both trade liberalisation (through the HOSS mechanism) and technological change could be responsible for the observed pattern of increased relative demand for skilled labour. Instead, in developing countries the two processes are supposed to have opposite effects, as follows (for an extensive analysis, see Lee and Vivarelli, 2004 and 2006).

On the one hand, technological change could shift the labour demand in favour of more skilled workers. The SBTC hypothesis is in fact based on the idea that there is close complementarity between new technologies and skilled workers, given that only the latter are fully able to implement the former. One of the first arguments for the SBTC hypothesis emanates from the work of Arrow (1962). Arrow introduced the notion of learning-by-doing, which implies that experience in the application of a given technology in the production process leads to increased efficiency over time. An implication of this idea is that an educated labour force should learn faster than a less educated group. Industries with more rapid technological progress may thus favour workers with greater potential for learning (Wolff, 2006). A second rationale comes from Nelson and Phelps' (1966) model, which stresses that a more educated workforce may make it easier for a firm to adopt and implement new technologies. The idea is that educated workers are more able to evaluate and adapt innovations and to learn new functions and routines than less educated ones.

On the other hand, the HOSS mechanism predicts that a developing country trading with skill-abundant developed economies should specialise in the production of unskilled-labour-intensive goods and therefore experience a relative increase in the demand for unskilled labour. 
However, if the HOSS assumption of homogeneous production functions and identical technologies between countries is relaxed, then international openness may facilitate technology diffusion ${ }^{3}$ from developed to developing countries, implying that trade and technological change are complementary rather than alternative mechanisms. Robbins (2003) called the effect of in-flowing technology resulting from trade liberalisation the 'skill-enhancing trade (SET) hypothesis'. The idea is that trade liberalisation accelerates flows of imported embodied technology (in machineries, intermediate inputs, components and final goods that can act as benchmarks for domestic production and can be subjected to reverse engineering) to developing countries, inducing an adaptation to the modern skill-intensive technologies currently used in developed countries, and resulting in an increase in the demand for skilled workers (for a more extensive analysis, see Vivarelli, 2004).

Turning our attention to the empirical literature, a large number of works have documented the relevance of the SBTC hypothesis for industrialised countries (ICs), ${ }^{4}$ while the evidence on developing countries (DCs) is scant.

For instance, Berman and Machin (2000 and 2004) studied the role of SBTC in increasing the demand for skills, trying to determine to what extent SBTC moves across international borders, thereby altering the skill structure of labour markets. They analysed the changes in the non-production wage-bill share in 37 countries $^{5}$ for the 1970-80 and 1980-90 time periods and found that in the '70s high-income countries experienced a great increase in skilled wages in their total manufacturing wage bill (most of which was due to within-industry skill upgrading). In the 1980s the skilled wage bill share increased in middle-income countries as well, to a similar extent as in high-income countries. They then showed that the US industry pattern of skill upgrading during the "70s was a good predictor of industry skill upgrading in middleincome countries in the '80s, suggesting that the same industries had increased their

\footnotetext{
${ }^{3}$ Keller (2004) and Piva (2003) provide complete surveys of the literature on international technology diffusion and show that trade openness turned out to be a key channel of technology adoption in developing countries. International technology transfer in fact represents a crucial determinant of technological upgrading in DCs (Krugman, 1979; De Long and Summers, 1993). While some firms are engaged in the creation of new technologies, most simply imitate or adapt existing production techniques to local conditions (Evenson and Westphal, 1995; Almeida and Fernandes, 2007).

${ }^{4}$ See for example Berman et al. (1994) and Autor, Katz and Krueger (1998) for the US; Haskel and Heden (1999) for the UK; Piva, Santarelli and Vivarelli (2005) for Italy; Machin and Van Reenen (1998) for a panel of seven OECD countries.

${ }^{5}$ They divided the sample into three subgroups: high-income, middle-income and low-income countries.
} 
proportion of skilled workers. Moreover, it appeared that the patterns in middle-income countries were due to the adoption of the same kinds of skill-biased technologies that had permeated into industries in the developed world - in fact, the measure of industry skill upgrading in the middle-income group was positively correlated with global technology indicators (computer usage and R\&D intensity). Thus, their results suggested that SBTC had been transferred rapidly from the developed world to middleincome countries and emphasised the pervasive nature of SBTC.

Conte and Vivarelli (2007) studied the impact of technological transfer on the employment of skilled and unskilled labour in a sample of low- and middle-income countries. By using a direct measure of embodied technological transfer - namely the trade flows from ICs of those goods which reasonably incorporate technological upgrading - they found that imported skill-biased technological change is one of the determinants of the increase in the relative demand for skilled workers within DCs.

Finally, Meschi and Vivarelli (2009) analysed the impact of trade openness on income distribution in a panel of developing countries. Their results suggested that total aggregate trade flows are not significantly related with income inequality in DCs. However, once they disaggregated trade flows according to their areas of origin/destination, they found a significant inequality-enhancing effect for trade with more advanced countries, possibly due to technological transfer and skill-enhancing trade.

Turning our attention to country-specific evidence, Hanson and Harrison (1999), using data on Mexican manufacturing plants, found that firms that receive FDI, acquire technology through licensing agreements or import materials, tend to hire more skilled workers. However, they found insignificant relationships for other measures of technological change. A similar result was obtained by Feenstra and Hanson (1997) who used data on 2-digit Mexican industries for the period 1975 to 1988 and found that FDI were positively correlated with the relative demand for skilled labour and that FDI could account for a large portion of the increase in the skilled labour share in total wages.

Pavcnik (2003) examined whether investment and adoption of skill-biased technology associated with trade liberalisation contributed to within-industry skill upgrading in Chilean plants during the '80s. In particular, using a restricted variable 
translog cost function approach, she investigated whether plant-level measures of capital investment, i.e. the use of imported materials, foreign technical assistance and patented technology, did affect the relative demand for skilled workers. Her results suggested that capital deepening provided a possible explanation for the growing relative demand for skilled workers. However, once she controlled for unobserved plant characteristics, the relationship between skill upgrading and the three technology measures disappeared, suggesting that plant adoption of foreign technology was not so obviously associated with plant skill upgrading. Fuentes and Gilchrist (2005) extended her analysis over an additional nine-year time span to cover the period 1979-1995. In contrast with Pavnick's findings, they found a robust association between the demand for skilled workers and the adoption of new technologies - measured by foreign patent usage - even after controlling for unobserved plant-level heterogeneity ${ }^{6}$.

Similarly, Mazumdar and Quispe-Agnoli (2002) found evidence that imported skillbiased technical change was responsible for rising wage inequality in Peru, following trade liberalisation there in the early '90s. They identified the channel as being the skillbiased technology embodied in imported machinery.

As far as we know, Gorg and Strobl's paper (2002) is the only work in this field focusing on a low-income country. They analysed a panel of manufacturing firms in Ghana over the '90s in order to determine whether imports of technology-intensive capital goods or export activities might provide an explanation for the increase in the relative wages of skilled workers in Ghana. Their results suggested that while the purchase of foreign machinery for technological purposes had significantly raised the relative demand for skilled labour, a greater participation in the world output market via exporting activities did not play a direct role in the skill composition of manufacturing firms in Ghana.

\section{Data}

The data used in this paper are drawn from the Annual Manufacturing Industry Statistics, provided by the Turkish Statistical Institute (TurkStat, formerly known as the

\footnotetext{
${ }^{6}$ By using a different methodology relying on individual-level data (Labour Force Survey), Beyer et al. (1999) also found that trade openness did raise the skill premium in Chile. However, they argued that the explanation for this effect went beyond technological transfers or a sector-biased technical progress.
} 
State Institute of Statistics, SIS). The database covers the 1980-2001 period and includes all private firms employing at least ten employees and all public firms. ${ }^{7}$ In terms of value added, it accounts for around $90 \%$ of all (formal sector) manufacturing output.

This database provides a wide array of information on each individual firm. For each year, firms provide detailed information on aspects such as size and composition of workforce, wages, output, input, sales, and investments among others. All variables are expressed in 1994 Turkish Lira, using sector-specific deflators.

Employment is measured as the number of workers hired per year and is split into two broad categories: production workers and administrative workers. Production workers include technical personnel, foremen and supervisors, and all those who work physically in the production activities. The administrative category includes management and administrative personnel and officers. We use these two categories of workers to distinguish between skilled labour (administrative workers) and unskilled labour (production workers) ${ }^{8}$.

The average number of firms per year is about 9600 in the private sector and about 400 in the public sector. Firms are classified by type of activity in accordance with the “International Standard Industrial Classification” (ISIC Rev.2). Table 1 reports the distribution of firms across the two-digit ISIC sectors.

\section{INSERT TABLE 1 HERE}

\footnotetext{
${ }^{7}$ Strictly speaking, the observation unit is a plant that has decision-making authority and keeps its own accounts. Since most of the firms are single plant firms, we use the terms firm and plant interchangeably. 8 The classification of workers into "production" and "non-production" groups in order to approximate skilled and unskilled labour respectively is very common in the literature: among others, Berman, Bound, and Griliches (1994) Feenstra and Hanson (1996), Leamer (1998) used a production/non-production classification. Although this categorisation is not ideal (as skills are better described by classifications based on educational characteristics), the production and non-production distinction is often the only one available in firm-level data. Moreover, Berman, et al. (1994) argue that identifying skilled and unskilled labour on the basis of job classifications and educational attainment leads to very similar results. They show that the proportion of non-production workers shows the same tendency to increase as the proportion of skilled workers in the US manufacturing sector. Indeed, the survey also provides a more detailed disaggregation of skill-types: for each year it reports the number of workers with different qualifications. These data would allow us to build a more precise measure of skilled workers, defined as the sum of skilled production workers (high-level and medium-level technical personnel) and skilled administrative workers (management and administrative personnel). Unfortunately, the survey does not provide wage data for this disaggregation. Therefore, our analysis will be based on the broad distinction between production and administrative labour.
} 
Data on international trade are collected by TurkStat and provide information on trade flows in each of 86 four-digit ISIC (Rev.2) sectors. Moreover, for each year and sector, the data enable us to disentangle trade flows according to their origin and destination areas. In particular, it is possible to distinguish if imports/exports are from/to ICs and DCs.

\section{Economic trends and descriptive evidence}

This section provides some stylised facts on the recent process of trade liberalisation in Turkey (section 4.1) and describes the main simultaneous trends in the Turkish labour market (section 4.2). In particular, we will look at the evolution of skilled versus unskilled relative wages and employment, in order to determine whether the relative demand for skilled labour did in fact increase during the phase of rapid integration of Turkey's economy into the international markets. Finally, in Section 4.3, we will decompose the relative aggregate demand shift into its between- and within-industry components.

\subsection{Trade Liberalisation}

Until 1980 Turkish economic and trade policies were characterised by importsubstituting (IS) industrialisation under heavy state protection. Despite good performance in terms of economic growth, IS strategy led to a number of problems which became unsustainable at the end of the 1970s: substantial inefficiency at the firm level (Celasun, 1994), macroeconomic instability and high unemployment, high inflation and severe balance of payments difficulties (Senses, 1994). The consequent growing public sector deficits and import shortages contributed to the acceleration of inflation which reached the average rate of 69\% during 1978-80. All these problems had a detrimental impact on the manufacturing sector, which registered negative growth rates in 1978-80.

In January 1980, a comprehensive structural adjustment reform program (SSAP ${ }^{9}$ ) was launched under the guidance and auspices of the International Monetary Fund and

\footnotetext{
${ }^{9}$ SSAP: Stabilization and Structural Adjustment Program.
} 
the World Bank. A major component of the reform package consisted in policy changes to achieve greater openness; this liberalisation process can be divided into two distinct phases (Yeldan, 2000 and Taymaz and Yilmaz, 2007). The first covers roughly the period 1981-1988, and its main characteristic is structural adjustment through export promotion and commodity trade liberalisation, albeit under a foreign exchange system of regulated foreign capital inflows. The second phase started in 1989 with the elimination of controls on foreign capital transactions and the declaration of convertibility of the Turkish Lira. In this second period the most important changes in the trade regime in Turkey were embodied in the Custom Union (CU) between the EU and Turkey (January 1996) and the subsequent Free Trade Agreements (FTAs) signed with the European Free Trade Association countries, Israel, and the Central and Eastern European (CEE) countries (2001).

As a result of these changes in trade policy, the volumes of Turkish exports and imports increased substantially as of the early '80s. Figure 1 plots the evolution of exports and imports as a percentage of total manufacturing output over the sample period, distinguishing trade flows according to their origin and destination areas.

\section{INSERT FIGURE 1 HERE}

The figure underlines the significant growth in imports and exports over the 19802001 period. Moreover, it shows that the bulk of imports came from industrialised countries (ICs). Exports patterns instead changed over time: at the beginning of the period exports to ICs and to DCs made up equivalent proportions of manufacturing output, while as of 1985 exports to ICs significantly increased with respect to those to DCs.

During the same period, total FDI flows increased as well, both in absolute terms and as a share of GDP. Figure 2 shows these trends for the 1975-2001 period. The figure reveals that until 1980 the level of FDI in Turkey was very low. The reason for this is the restrictive bureaucratic practices of government institutions - especially the State Planning Organization - who were suspicious of foreign capital (Taymaz and Lenger, 2006). In the early '80s, in line with the general outward-oriented strategy, the administrative system regulating FDI was reorganised in order to simplify investment 
procedures and to eliminate ambiguities arising from the fragmented bureaucratic structure; moreover, the discriminatory treatment of foreign investors was gradually eliminated. The complete liberalisation of capital accounts and the elimination of certain restrictions on FDI in 1989 provided additional impetus for foreign investment.

\section{INSERT FIGURE 2 HERE}

Summing up, what emerges from this brief overview is that over the '80s and '90s the Turkish economy became increasingly connected with the world market. In the next section we will analyse the trends of relative employment and wages, trying to determine whether the demand for skilled labour changed during the years of globalisation.

\subsection{Trends in the Labour Market}

Figure 3 plots the simultaneous trends in relative wages (right axis) and relative employment (left axis) in the private sector over the 1980-2001 period. The figure clearly shows that both relative wages and relative employment tended to rise. This is particularly obvious during the '80s when trade liberalisation was especially rapid.

\section{INSERT FIGURE 3 HERE}

The observed simultaneous increase in relative employment and relative wages necessarily implies an upward shift in the relative demand for skilled labour (see Berman et al., 2005).

Another way to evaluate whether the relative demand for skilled labour increased, and to distinguish the effects of labour supply from those of labour demand, is to observe the evolution of the labour cost share of skilled workers ${ }^{10}$, under the hypothesis of elasticity of substitution between skilled and unskilled labour equal to one (Berman and Machin, 2000 and Berman et al., 2005). If the elasticity of substitution is one, the

\footnotetext{
${ }^{10}$ The labour cost share is the share of total labour costs accruing to skilled workers. Unlike other papers, which look at the skilled workers' share of the wage bill, here we focus on labour cost. The labour cost is given by wages plus employees' social contribution and premiums. Since we are interested in the plantlevel determinants of the demand for labour, the effective costs are important - including the non-wage elements firms have to sustain.
} 
labour cost share of skilled labour (SLCSH) is invariant to movements along the relative demand curve and therefore SLCSH can be considered a measure of the demand for skills ${ }^{11}$.

Figure 4 plots the evolution of SLCSH during the sample period, confirming the rising demand for skills.

\section{INSERT FIGURE 4 HERE}

\section{3: Decomposition analysis}

The previous figures document an increasing demand for skilled labour that occurred simultaneously with a rapid increase in international trade. An initial attempt to determine the main forces behind skill upgrading can be made by splitting the aggregate change in the demand for skilled labour into its between- and within-industry components. The aggregate increase in the demand for skills may be driven by (a) employment reallocation across industries (for a number of reasons, such as trade shift, structural change, changing tastes, or changes in economic policy) or by (b) skill upgrading within industries (mainly due to technological change). Following Berman, et al. (1994) we decompose the aggregate change in labour cost share for skilled workers ( $\triangle S L C S H$ ) for $i=1, \ldots, \mathrm{N}$ industries (with $\mathrm{N}=86$ ) over a period of time according to the following formula:

$$
\Delta S L C S H=\sum_{i=1}^{N} \Delta S L C S H_{i} \bar{P}_{i}+\sum_{i=1}^{N} \Delta P_{i} \overline{S L C S H_{i}}
$$

\footnotetext{
${ }^{11}$ The labour cost share of skilled workers can be expressed as: $S L C S H=\frac{w_{s} S}{w_{S} S+w_{l} L}=\frac{w_{s} S}{w E}$ where $w$ is wages, $s$ subscript denotes skilled labour, $l$ subscript denotes low-skilled labour, $\mathrm{S}$ and $\mathrm{L}$ are respectively the number of skilled and low-skilled workers and $\mathrm{E}$ is total employment. Taking the logarithm, the formula can be decomposed as follows: $\log (S L C S H)=\log \left(w_{s} / w\right)+\log (S / E)$. If the elasticity of substitution between $S$ and $\mathrm{L}$ is one, $S L C S H$ is constant along a relative demand curve, so that the log change in relative wages and that of relative employment sum to zero: $\Delta \log (S L C S H)=\Delta \log \left(w_{s} / w\right)+\Delta \log (S / E)=0$.
} 
The first term is the within-industry component of skill upgrading (weighted by $\overline{P_{i}}$, the relative size of industry $i$ - i.e. the share of industry $i$ 's labour cost in the aggregate labour cost - where the bar is a time mean). The second term measures the contribution of between-industry shifts, i.e. how much bigger or smaller an industry is becoming over time (weighted by time-averaged skill demand).

The results of this decomposition are shown in Table 2. We report the decomposition obtained from the full sample period (in the first row of the table) as well as the decomposition over different sub-sample periods defined according to the timing of the main Turkish policy changes and the major cycles of adjustment-growth-recession ${ }^{12}$. The first period (1980-1983) corresponds to the first phase of trade liberalisation, characterised by an export promotion strategy. The second period of trade liberalisation took place in the period 1983-88, when most of the tariffs and non-tariff barriers to imports were reduced or eliminated. These two phases correspond to the growth cycle promoted by export orientation, followed by the recession of 1988. The second cycle (1988-93) was generated by foreign capital inflows following financial deregulation and came to an end with the eruption of the 1994 financial crisis (the fourth sub-period in the table). The last growth cycle was that of 1995-2000, short-circuited by the second financial crisis in 2001.

\section{INSERT TABLE 2 HERE}

The results suggest that the aggregate labour cost share of skilled workers rose by 14.8 percentage points over the full sample period (see also Figure 4). The table also shows that this increase was mainly driven by within-industry variation, which represents more than 88 percent of the overall change. Looking at the results for different periods, it emerges that in each phase the within-sector component is positive and dominant (except for the 1988-93 sub-period), suggesting that aggregate demand shifts are persistently due to within-sector upgrading. The aggregate change and the within-industry component are particularly high in the 1983-88 interval, which

\footnotetext{
${ }^{12}$ See Yeldan (2000) for a detailed description of macroeconomic phases in the post-1980 Turkish economy.
} 
corresponds to a period of rapid trade liberalisation during which most import barriers were eliminated.

While many papers propose the dominance of the within-industry component as evidence for the relevance of the SBTC hypothesis (e.g Berman, Bound and Machin, 1998), rejecting the importance of trade-based explanations ${ }^{13}$, we instead argue that the two explanations are not necessarily alternative, especially in the case of middle-income open economies such as Turkey. Indeed, trade intensification and SBTC may be complementary in explaining the observed dominance of the within-industry component in the increase in the demand for skills. Trade liberalisation may in fact have fostered the process of technological upgrading by increasing the magnitude of the 'within' component. The fact that the within-industry effect was higher in the periods of more intensive trade liberalisation would confirm this idea, suggesting that trade may have played a role by fostering and accelerating the adoption of the new skill-biased technologies.

\section{Econometric Analysis}

We are interested in determining whether the changes in the skilled labour cost share (SLCSH) are correlated to any measure of technology adoption (as the SBTC literature predicts) and to exposure to international markets. As discussed above, in the case of middle-income developing countries such as Turkey trade openness may be a complementary driver force in the fostering of technological upgrading. Our empirical strategy is explained in the next section, while in Section 5.2 we present and discuss the results.

\footnotetext{
${ }^{13}$ Feenstra and Hanson (2001) challenge the conclusions of many previous works that use the evidence of within-industry shift as an argument against the relevance of trade. They argue that "this line of reasoning emphasizes trade in final goods and ignores the globalization of production and recent dramatic increases in trade in intermediate inputs. Much recent growth in trade has resulted from firms breaking industries apart by locating low-skill activities in low-wage countries and high-skill activities in high-wage countries. (...). Recent literature shows that trade to merchandise GDP ratios have risen sharply in recent years, with much of the growth in trade attributable to intermediate inputs, that changes in the relative prices of domestic versus imported goods are consistent with trade shifting out the relative demand for skilled labor, and that trade in intermediate inputs is consistent with skill upgrading being a withinindustry phenomenon” (Feenstra and Hanson, 2001, pp. 46-47).
} 


\subsection{Empirical Strategy}

Our empirical strategy consists in the estimation of a cost share equation whereby changes in the wage bill share in a given firm are related to observable measures of international openness and technology adoption. Drawing on Berman et al. (1994), Doms et al. (1997) and Machin and Van Reenen (1998), the factor share equation is derived from a translog cost function ${ }^{14}$ where the two factors of production are skilled (S) and unskilled (L) labour, while physical capital (K) and "technological capital” (T) are assumed to be quasi-fixed. Consequently, the cost function assumes the following form:

$$
\begin{aligned}
& \log C=\alpha_{0}+\sum_{i=S, L} \beta_{i} \log w_{i}+\sum_{i=S, L} \sum_{j=S, L} \beta_{i j} \log w_{i} \log w_{j}+\beta_{q} \log Q+\sum_{i=S, L} \beta_{i q} \log w_{i} \log Q+ \\
& \beta_{k} \log K+\sum_{i=S, L} \beta_{i k} \log w_{i} \log K+\beta_{T} \log T+\sum_{i=S, L} \beta_{i T} \log w_{i} T
\end{aligned}
$$

where $C$ are variable costs. The $\beta$ parameters measure the effect on total cost of factor prices $\left(\mathrm{w}_{\mathrm{i}}\right)$, output $(\mathrm{Q})$, capital stock $(\mathrm{K})$ and technology $(\mathrm{T})$.

According to Shephard`s Lemma, the optimal cost minimising demand for an input can be derived through differentiation of the cost function with respect to its price. Therefore, we obtain the cost share of skilled labour (SLCSH) which can be expressed as follows ${ }^{15}$ :

$$
S L C S H=\alpha_{S}+\sum_{i=S, L} \beta_{S} \log \left(w_{S} / w_{L}\right)+\beta_{S K} \log K+\beta_{S Q} \log Q+\beta_{S T} \log T
$$

Therefore, the estimating equation of the labour cost share of skilled workers can be expressed as a stochastic form of equation (3). In particular, for firm $i$ at time $t$ it takes the following form:

$$
S L C S H_{i t}=\alpha_{0}+\beta_{1} \log \left(w_{S} / w_{L}\right)_{i t}+\beta_{2} \log \left(K_{i t}\right)+\beta_{3} \log \left(Q_{i t}\right)+\beta_{4} \log \left(T_{i t}\right)+\varepsilon_{i}+u_{i t}
$$

\footnotetext{
${ }^{14}$ As emphasised by Pavcnik (2003), the translog cost function is very appealing because it provides a second-order approximation to any cost function and does not impose any restrictions on the substitutability of the various inputs.

${ }^{15}$ Equations 3 and 4 are derived after imposing homogeneity of degree one in prices, which implies that $\sum_{i=S, L} \beta_{i j}=\sum_{j=S, L} \beta_{i j}=\sum_{i=S, L} \sum_{j=S, L} \beta_{i j}=\sum_{i=S, L} \beta_{i T}=\sum_{i=S, L} \beta_{i k}$
} 
In such a specification, $\beta_{2}$ captures the potential capital-skill complementarity (see Griliches, 1969). The output coefficient allows us to test the constant-returns hypothesis, which implies that input shares are invariant to scale (if $\beta_{3}>0$, this hypothesis is violated, indicating that in faster-growing firms the labour cost share of skilled workers also increases). Moreover, the log output allows us to control for business cycle fluctuations; such fluctuations may occur if firms are more likely to lay off unskilled workers than skilled workers during a temporary downturn (see Fuentes and Gilchrist, 2005). $\beta_{4}$ represents our coefficient of interest and captures the impact of different technology-related variables. In this context, 'technology' has to be interpreted in a wider sense; we will use different variables which are potentially channels of technological upgrading: besides the usual proxies of technological change such as R\&D expenditures, we will also include variables describing international technological transfer and firms’ international exposure.

Starting from equation (4), we employ a dynamic specification in order to account for the occurrence of significant employment adjustment costs which determine serial correlation in the labour-cost-share series. Moreover, as is usual in this literature (see Chennels and Van Reneen, 1999), we drop the endogenously-determined relative wage term, since it is directly involved in the construction of the dependent variable. We instead include time dummies which should capture the movements in the wage bill share due to supply shifts as well as other economy-wide mechanisms ${ }^{16}$. Therefore, our estimating equation will be:

$$
S L C S H_{i t}=\alpha_{0}+\beta_{1} S L C S H_{i t-1}+\beta_{2} \log \left(K_{i t}\right)+\beta_{3} \log \left(V A_{i t}\right)+\beta_{4} \log \left(T_{i t}\right)+\eta_{t}+\varepsilon_{i}+u_{i t}
$$

where the subscripts $i$ and $t$ denote respectively firms and years; SLCSH is the skilled workers labour cost share; $\mathrm{K}$ is capital ${ }^{17}, \mathrm{VA}$ is the value added, $\mathrm{T}$ is a vector of mechanisms leading to technological upgrading, $\eta_{t}$ are year dummies, $\varepsilon_{\mathrm{i}}$ are the individual fixed effects and finally $u_{i t}$ are the usual error terms. All variables are

\footnotetext{
16 This is a common solution adopted in most of the literature. See, among others, Machin and Van Reneen (1998), Pavcnik (2003) and Berman et al. (2005)

${ }^{17}$ Capital is proxied by annual depreciation allowances, as in Taymaz and Lenger (2006)
} 
expressed in natural logarithms. In order to control for fixed firm's effects $\left(\varepsilon_{\mathrm{i}}\right)^{18}$, we estimate this equation in differences. The final specification is thus as follows:

$$
\Delta S L C S H_{i t}=\beta_{1} \Delta S L C S H_{i t-1}+\beta_{2} \Delta \log \left(K_{i t}\right)+\beta_{3} \Delta \log \left(V A_{i t}\right)+\beta_{4} \Delta \log \left(T_{i t}\right)+\eta_{t}+\Delta u_{i t}
$$

where $\Delta$ is the first difference operator.

However, as in any dynamic specification, the correlation of the lagged dependent variable with the error term implies an endogeneity problem. To solve this problem, Arellano and Bond (1991) proposed using a Generalized Method of Moment (GMM) estimation, in which the instrument matrix includes all (or at least more) previous level values of the lagged dependent variable (GMM-DIFF estimator). However, the GMMDIFF estimator is found to be weak if cross-section variability dominates time variability and if there is a strong persistence in the investigated time series (Bond et al., 2001). An efficiency improvement may be obtained through the additional consideration of the original equation in levels, instrumented by their own differences (Blundell and Bond, 1998, GMM SYS). Indeed, in the following econometric exercise, the availability of R\&D and trade variables limited the analysis to 17,462 private firms over the sub-period 1992-2001 for a total of 88,712 observations. Moreover, the correlation between SLCSH and SLCSH (-1) turned out to be 0.766 , while the coefficient of the linear regression of SLCSH on SLCSH (-1) was equal to 0.769. Since both the conditions calling for the more comprehensive GMM-SYS methodology seem to characterise our data, we chose this estimation method.

\subsection{Econometric Results}

Starting from eq. (6) and after considering persistence (SLCSH (-1)), capital complementarity (K) and firm's size (VA), we used our data to characterise T, that is the vector of the additional mechanisms leading to skill upgrading.

\footnotetext{
${ }^{18}$ Chennels and Van Reneen (1999) stress the importance of controlling for fixed effects in this context. There is in fact unobserved heterogeneity across firms that may result in biased estimations. This is because certain types of firms are more or less likely to experience skill biases due to the specificities of their production processes and the possible different abilities of their managers.
} 
First, we included a dummy variable for R\&D performers (R\&D_dum), in order to identify a possible effect of pure SBTC on the demand for skilled labor. We expect a positive sign for the effect of R\&D_dum on SLCSH.

However, since we are interested in the impact of trade-related technological transfer from abroad, we used other indicators able to capture technology adoption. The first (ttrans) was created by looking at foreign patent and licence usage. Ttrans is a dummy variable which is equal to one if a firm in a given year obtained the right to use foreign technology (know-how or patent) by a license agreement. This variable is particularly interesting since it describes the process of (disembodied) technology adoption and thus captures incremental innovations which allow a progressive catch-up to the world technology frontier (Almeida and Fernandes, 2007).

The second proxy of integration into global markets is constructed by looking at the firms' ownership structure; foreign is a dummy equal to 1 if $10 \%$ or more of a firm's capital is owned by foreigners. In this way, we are able to evaluate the skill-biased impact of FDI (the expected sign is positive; see previous empirical evidence surveyed in Section 2).

Thirdly, we included a dummy variable xdum which is equal to 1 if the firm is an exporter and 0 otherwise ${ }^{19}$. Following the discussion presented in Section 2, we expect the coefficient of xdum to have a positive sign in the equation as well, as exporters should be more likely to adopt new technologies than firms selling exclusively to the domestic market.

In order to analyse the skill-enhancing-trade hypothesis in more detail, we also looked at the possible role of imports. We expect import penetration to be positively correlated with the demand for skills: imports may in fact act as a channel for technological transfer. Ideally, we would have liked to look at imports directly at the firm level, but unfortunately our dataset does not provide this information. Therefore we used 1990 and 1998 input-output tables to calculate the share of imported input to total input at the sectoral level (37 manufacturing industries) and we applied the obtained figures to all the firms belonging to a given sector (foreign input $=$ finput ${ }^{20}$. In addition,

\footnotetext{
${ }^{19}$ Ideally, we would have used data on the value of exports. However, the available microdata do not provide this information and we only had information on whether a firm is an exporter or not.

${ }^{20}$ The data for the single years were estimated by interpolation (for 1991-1997), and extrapolation (for 1999-2001).
} 
we disaggregated this variable according to the geographical area of origin of the imported input, distinguishing whether imports were from developed countries (fdcinput) or developing countries (fldcinput). Table 3 shows our results and diagnostic tests $^{21}$.

\section{INSERT TABLE 3 HERE}

Together with strong persistence of SLCSH, our results underline the occurrence of capital-skill complementarity: the capital coefficient is always positive and highly significant which means that, ceteris paribus, firms with higher capital intensity also demand a higher share of skilled workers. The real value added also enters the equation significantly, indicating that plant size is not neutral with respect to the relative demand for skills.

Turning our attention to the in-house technology variable, it emerges that the occurrence of R\&D investment has a positive and significant impact on the skilled labour cost share. Consistently with many other works focusing on developed economies, expenditures in $\mathrm{R} \& \mathrm{D}$ tend to raise the demand for skilled labour, indicating the diffusion of the SBTC effect to middle-income developing countries such as Turkey.

If we now focus on the three dummies measuring a firm's exposure to international technological transfer, the estimation results show a positive and significant relationship between these regressors and the labour cost share of skilled workers. The variable that

\footnotetext{
${ }^{21}$ The Wald test, asymptotically distributed as a $\chi^{2}$ where the degrees of freedom equate the number of restricted coefficients, allows us to test the overall significance of the independent variables; it always rejects the null hypothesis of insignificant coefficients. Three rows report the Lagrange Multiplier (LM) tests for first, second and third order serial correlation of the residuals proposed by Arellano-Bond (1991). The test is applied to the residuals of the first-differenced equation, and the null hypothesis is the absence of $n$-th order serial correlation. The tests detect first- and second-order serial correlations, but reject serial correlation of higher order; hence, the GMM SYS estimator was implemented by using second, third and fourth lags of the dependent variable as instruments. The Sargan test of overidentifying restrictions verifies the overall validity of the GMM instruments where the null hypothesis suggests that the instruments are uncorrelated to some set of residuals. In our regression, the null hypothesis is always rejected; however we are not overly worried by the failure of the test for three reasons. First, the Sargan test "should not be relied upon too faithfully, as it is prone to weakness" (Roodman, 2006, p. 12). Second, in their Monte Carlo experiments Blundell and Bond (2000) "observe some tendency for this test statistic to reject a valid null hypothesis too often in these experiments and this tendency is greater at higher values of the autoregressive parameter" (Blundell and Bond, 2000, p. 329). Third, the very large number of observations makes the occurrence of a significant Sargan more likely: indeed, we repeated the test over random subsamples of one third of firms and it was not significant in most of the subsamples. These results (available upon request) indicate that it is the very large number of observations that makes the Sargan test likely to be statistically significant.
} 
directly measures international technological transfer (ttrans) and the variables capturing international openness through FDI and export exposure exert a significant impact on the demand for skills (statistically weaker in the case of export). These findings support the argument that involvement in the global market plays a crucial role in fostering SBTC.

Interestingly, the results show that firms belonging to those sectors that most raised their imported inputs also experienced a higher increase in the labour cost share of skilled workers. Import penetration facilitated the adoption of new technologies, thus shifting production towards more skill-intensive technologies (column 3 in Table 3).

However, if technological diffusion is the channel through which imports increase the demand for skilled labour, we should expect a greater impact of imports from industrialised countries, where the potential for innovation diffusion comes from. The results from this disaggregated analysis are reported in the last column of Table 3. Indeed, it emerges that only imports from industrialised countries are significantly related to changes in the skilled labour cost share.

\section{Concluding Remarks}

This paper has reported evidence on the relationship between trade openness, technology adoption and relative demand for skilled labour in Turkish manufacturing firms.

We first outlined the simultaneous increase in international openness and in demand for skills at a descriptive level. In particular, we showed that in the aftermath of the rapid and thorough liberalisation process, the relative demand for skilled labour increased substantially.

We then investigated the possible sources of such an increase in the relative labour demand by decomposing the aggregate shift in the demand for skills into its within- and between-sector components. The analysis revealed that the aggregate shift was mainly due to the within-sector component, suggesting the relevance of the SBTC hypothesis.

Finally, we estimated a cost share equation whereby changes in the wage bill share of skilled workers in a given firm are related to observable measures of international 
exposure and technology adoption. It emerged that R\&D expenditures were positive and significantly related to skill upgrading. This result supports the SBTC argument in the case of a middle-income country such as Turkey. Moreover, we tested the impact of three variables reflecting firms' international engagement: a dummy variable for technological transfer from abroad, a dummy variable for firms characterised by foreign ownership and a dummy variable for exporting firms. All three turned out to be positive and significant, emphasising the importance of globalisation in fostering skill upgrading.

Our data also allowed us to investigate the direct impact of import flows in shaping the relative demand for skills. The results showed that on average firms belonging to those sectors that most raised their share of imported inputs to total inputs also experienced a higher increase in the labour cost share of skilled workers. This finding is consistent with the idea that imports imply a transfer of new technologies which are more skill-intensive than those previously in use in domestic markets, thus leading to a higher demand for skilled labour. This idea is reinforced by the finding that only imports from industrialised countries, where the potential for innovation diffusion originates, entered the regressions significantly.

Overall, the analysis reveals that in Turkey the relative demand for skills increased substantially over the 1980-2001 period, when Turkey underwent radical policy changes favouring trade liberalisation. The descriptive evidence and the econometric estimates suggest that the interplay between trade openness and technology adoption played a key role in shifting the demand for labour towards more skilled workers. We thus provide evidence in which trade and technology are not treated as competing explanations, but are rather complementary in explaining the observed increase in the relative demand for skilled labour. Whether these results may be extended to other middle-income developing countries is a matter for further research. 


\section{References}

Abramovitz, M., (1986): “Catching-up, Forging Ahead and Falling Behind”, Journal of Economic History, Vol.46, pp. 385-406

Almeida, R. and Fernandes, A.M. (2007): "Openness and Technological Innovations in Developing Countries: Evidence from Firm-Level Surveys," IZA Discussion Papers N. 2907; Institute for the Study of Labor (IZA), Bonn.

Arellano, M. and Bond, S. (1991): "Some Tests of Specification for Panel Data: Monte Carlo Evidence and an Application to Employment Equations", Review of Economic Studies, Vol.58, pp. 277-297.

Arrow, K. (1962): “The Economic Implications of Learning by Doing”, Review of Economic Studies, Vol. 29, pp. 155-173.

Autor, D., Katz, L. and Krueger, A.B. (1998): "Computing Inequality: Have Computers Changed the Labor Market?”, Quarterly Journal of Economics, Vol. 113, pp. 1169-1214.

Berman, E., Bound, J. and Griliches, Z. (1994): "Changes in the Demand for Skilled Labor Within U.S. Manufacturing Industries,” Quarterly Journal of Economics, Vol. 109, pp. 367-398.

Berman, E., Bound, J. and Machin, S. (1998): "Implications of Skill-Biased Technological Change: International Evidence,” Quarterly Journal of Economics, Vol. 113, pp. 1245-80.

Berman, E. and Machin, S. (2000): "Skill-Biased Technology Transfer Around the World", Oxford Review of Economic Policy, Vol.16, pp. 12-22.

Berman, E. and Machin, S. (2004): "Globalization, Skill-Biased Technological Change and Labour Demand”, in Lee, E. and Vivarelli, M. (2004) (eds) “Understanding Globalization, Employment and Poverty Reduction”, Palgrave Macmillan, New York: pp. 39-66.

Berman, E., Somanathan, R. and Tan, H. (2005): "Is Skill-biased Technological Change here Yet? Evidence from Indian Manufacturing in the 1990", World Bank Policy Research Working Paper, N. 3761, World Bank, Washington DC.

Beyer, H., Rojas, P. and Vergara, R. (1999): “Trade Liberalization and Wage Inequality”, Journal of Development Economics, Vol. 59, pp 103-123.

Blundell, R. and Bond, S. (1998): "Initial Conditions and Moment Restrictions in Dynamic Panel Data models”, Journal of Econometrics, Vol. 87, pp. 115-143.

Blundell, R. and Bond, S. (2000): "GMM Estimation with Persistent Panel Data: an Application to Production Function”, Econometric Reviews, Vol. 19, pp. 321-340.

Bond, S., Hoeffler, A. and Temple, J. (2001): “GMM Estimation of Empirical Growth Models”, CEPR Working Paper N. 3048, Centre for Economic Policy Research (CEPR), London.

Celasun, M. (1994): “Trade and Industrialization in Turkey: Initial Conditions, Policy and Performance in the 1980s", in Helleiner, G.K (eds): "Trade Policy and Industrialization in Turbulent Times”, Routledge, London, pp. 453-484. 
Chennells, L. and Van Reenen, J. (1999): "Has Technology Hurt Less Skilled Workers? An econometric survey of the effects of technical change on the structure of pay and jobs”, IFS Working Paper, N. 27, Institute for Fiscal Studies (IFS), London.

Conte, A. and Vivarelli, M. (2007): "Globalization and Employment: Imported Skill Biased Technological Change in Developing Countries”, IZA Discussion Paper, N. 2797, Institute for the Study of Labor (IZA), Bonn.

Deardorff, A.V. (1998): “Technology, Trade, and Increasing Inequality: Does the Cause Matter for the Cure?”, Journal of International Economic Law, Vol. 1, pp. 353-376.

Doms, M., Dunne, T., Troske, K. (1997): "Workers, Wages and Technology”, Quarterly Journal of Economics, Vol. 112, pp. 253-290.

Evenson, R. and Westphal, L. (1995): “Technological Change and Technology Strategy”, in Srinivasan, T. N. and Behrman, J. (eds.) Handbook of Development Economics, North Holland Publishing Company, Amsterdam: Vol. 3.

Feenstra, R.C. and Hanson, G.H. (1996): “Globalization, Outsourcing, and Wage Inequality”, American Economic Review, Vol. 86, pp. 240-245.

Feenstra, R.C. and Hanson, G.H. (1997): "Foreign Direct Investment and Relative Wages: Evidence from Mexico’s Maquiladoras”, Journal of International Economics, Vol. 42, pp. 371-393.

Feenstra, R.C and Hanson, G.H. (2001): "Global Production Sharing and Rising Inequality: A Survey of Trade and Wages”, NBER Working Paper N. 8372, National Bureau of Economic Research, Cambridge (Mass.)

Fuentes, O. and S. Gilchrist (2005): “Trade Orientation and Labor Market Evolution: Evidence from Chilean Plant-level Data”, in Labor Markets and Institutions, edited by J. Restrepo and A. Tokman, Central Bank of Chile.

Görg, H. and Strobl, E. (2002): "Relative Wages, Openness and Skill-Biased Technological Change", IZA Discussion Papers N. 596, Institute for the Study of Labor (IZA), Bonn.

Griliches, Z. (1969): “Capital-skill Complementarity”, Review of Economics and Statistics, Vol. 51, pp. 465-468.

Hanson, G. and Harrison, A. (1999): “Trade and Wage Inequality in Mexico,” Industrial and Labor Relations Review, Vol. 52, pp. 271-288.

Haskel, J.E. and Heden, Y. (1999): “Computers and the Demand for Skilled Labour: Industry and Establishment-level Evidence for the UK”, Economic Journal, Vol. 109, pp. C68-C79.

Katz, L.F. and Murphy, K.M. (1992): "Changes in Relative Wages, 1963-1987: Supply and Demand Factors.” Quarterly Journal of Economics, Vol. 107, pp. 35-78.

Keller, W. (2004): “International Technology Diffusion”, Journal of Economic Literature, Vol. 42, pp. 752-782.

Krugman, P.R. (1979): “A Model of Innovation, Technology Transfer, and the World Distribution of Income”, Journal of Political Economy, Vol. 87, pp. 253-266. 
Krugman, P.R. and Lawrence, R. (1993): "Trade, Jobs, and Wages," NBER Working Papers, N. 4478, National Bureau of Economic Research.

Lall, S. (2004): "The Employment Impact of Globalization in Developing Countries", in Lee, E. and Vivarelli, M. (2004) (eds) "Understanding Globalization, Employment and Poverty Reduction", Palgrave Macmillan, New York: pp. 73-101.

Leamer, E. (1994): “Trade, Wages and Revolving Doors Ideas”, NBER Working Paper N. 4716, National Bureau of Economic Research, Cambridge (Mass.).

Leamer, E. (1998): “In Search of Stolper-Samuelson Effects on US Wages”, in Collins, S. (eds). "Imports, Exports and the American Worker", Brookings Institution Press, Washington D.C.: pp. 141-214.

Lee, E. and Vivarelli, M. (2004) (eds.): "Understanding Globalization, Employment and Poverty Reduction”, Palgrave Macmillan, New York.

Lee, E. and Vivarelli, M. (2006): “The Social Impact of Globalization in the Developing Countries, International Labour Review, Vol. 145, pp. 167-184.

Machin, S. and Van Reenen, J. (1998): “Technology and Changes in Skill Structure: Evidence from Seven OECD Countries,” Quarterly Journal of Economics, Vol. 113, pp. 1215-1244.

Mazumdar, J. and Quispe-Agnoli, M. (2002): "Trade and the Skill Premium in Developing Countries: the Role of Intermediate Goods and some Evidence from Peru," Working Paper 11, Federal Reserve Bank of Atlanta.

Meschi, E. and Vivarelli, M. (2009): “Trade and Income Inequality in Developing Countries”, World Development, forthcoming.

Nelson, R. and Phelps, E. (1966): "Investment in Humans, Technological Diffusion, and Economic Growth”, American Economic Review, Vol. 56, pp. 69-75.

Pavcnik, N. (2003): “What Explains Skill Upgrading in Less Developed Countries?”, Journal of Development Economics, Vol.71, pp.311-328.

Piva, M. (2003): "The Impact of Technology Transfer on Employment and Income Distribution in Developing Countries: a Survey of Theoretical Models and Empirical Studies”, International Policy Group Working Paper N.15, International Labour Office (ILO), Geneva.

Piva, M., Santarelli, E. and Vivarelli, M. (2005): "The Skill Bias Effect of Technological and Organisational Change: Evidence and Policy Implications," Research Policy, Vol. 34, pp. 141-157.

Robbins, D. (2003): "The Impact of Trade Liberalization upon Inequality in Developing Countries - A Review of Theory and Evidence", ILO Working Paper, n.13, International Labour Organization (ILO), Geneva.

Roodman, D. (2006): "How to do xtabond2: An introduction to "Difference" and "System" GMM in Stata”, CGD working paper n. 103, Center for Global Development (CGD), Washington DC.

Senses, F. (1994): "The Stabilization and Structural Adjustment Program and the Process of Turkish Industrialization: Main Policies and their Impact", in Senses (eds.): "Recent industrialization experience of Turkey in a global context”, Westport CT. Greenwood Press, London: pp. 51-73. 
Taymaz, E. and Lenger, A. (2006): "To Innovate or to Transfer? A Study on Spillovers and Foreign Firms in Turkey”, Journal of Evolutionary Economics, Vol. 16, pp. 137-153.

Taymaz, E. and Yilmaz, K. (2007): "Productivity and Trade Orientation: Turkish Manufacturing Industry before and after the Custom Union”, Journal of International Trade and Diplomacy, Vol. 1, pp. 127-154

Vivarelli, M. (2004): “Globalization, Skills and Within-Country Income Inequality in Developing Countries" in Lee, E. and Vivarelli, M. (2004) (eds): “Understanding Globalization, Employment and Poverty Reduction”, Palgrave Macmillan, New York: pp: 211-243.

White, H. (1980) “A Heteroskedasticity-Consistent Covariance Matrix Estimator and a Direct Test for Heteroskedasticity”, Econometrica, Vol. 48, pp. 817-838

Wolff, E. (2006): “Does Education Really Help?”, Oxford University Press, Oxford.

Wood, A. (1994): "North-South Trade, Employment, and Inequality: Changing Fortunes in a Skilldriven World”, Clarendon Press, Oxford.

Yeldan, E. (2000): "The Impact of Financial Liberalization and the Rise of Financial Rents on Income Inequality: the Case of Turkey”, UNU/WIDER Working Papers N. 206, UNU/WIDER, Helsinki. 


\section{Tables and Figures}

Table 1: Distribution of private and public firms across sectors

\begin{tabular}{lcc}
\hline ISIC Industry & Private Sector & Public Sector \\
\hline \hline & & \\
Food Beverages Tobacco & $18.28 \%$ & $53.27 \%$ \\
Textile and Clothing & $27.02 \%$ & $8.70 \%$ \\
Wood Products & $3.93 \%$ & $5.08 \%$ \\
Paper and Printing & $3.79 \%$ & $4.85 \%$ \\
Chemicals and Petroleum, Coal, Rubber and Plastic & $9.75 \%$ & $7.51 \%$ \\
Non-Metallic Mineral Prods. & $7.35 \%$ & $6.40 \%$ \\
Basic Metal & $4.39 \%$ & $3.33 \%$ \\
Metal Products, Machinery and Equipment & $24.41 \%$ & $10.63 \%$ \\
Other Manufacturing & $1.09 \%$ & $0.28 \%$ \\
\hline
\end{tabular}

Source: Own calculation from the Annual Manufacturing Industry Statistics

Figure 1: Exports and Imports (\% tot. manuf. output) by origin and destination areas
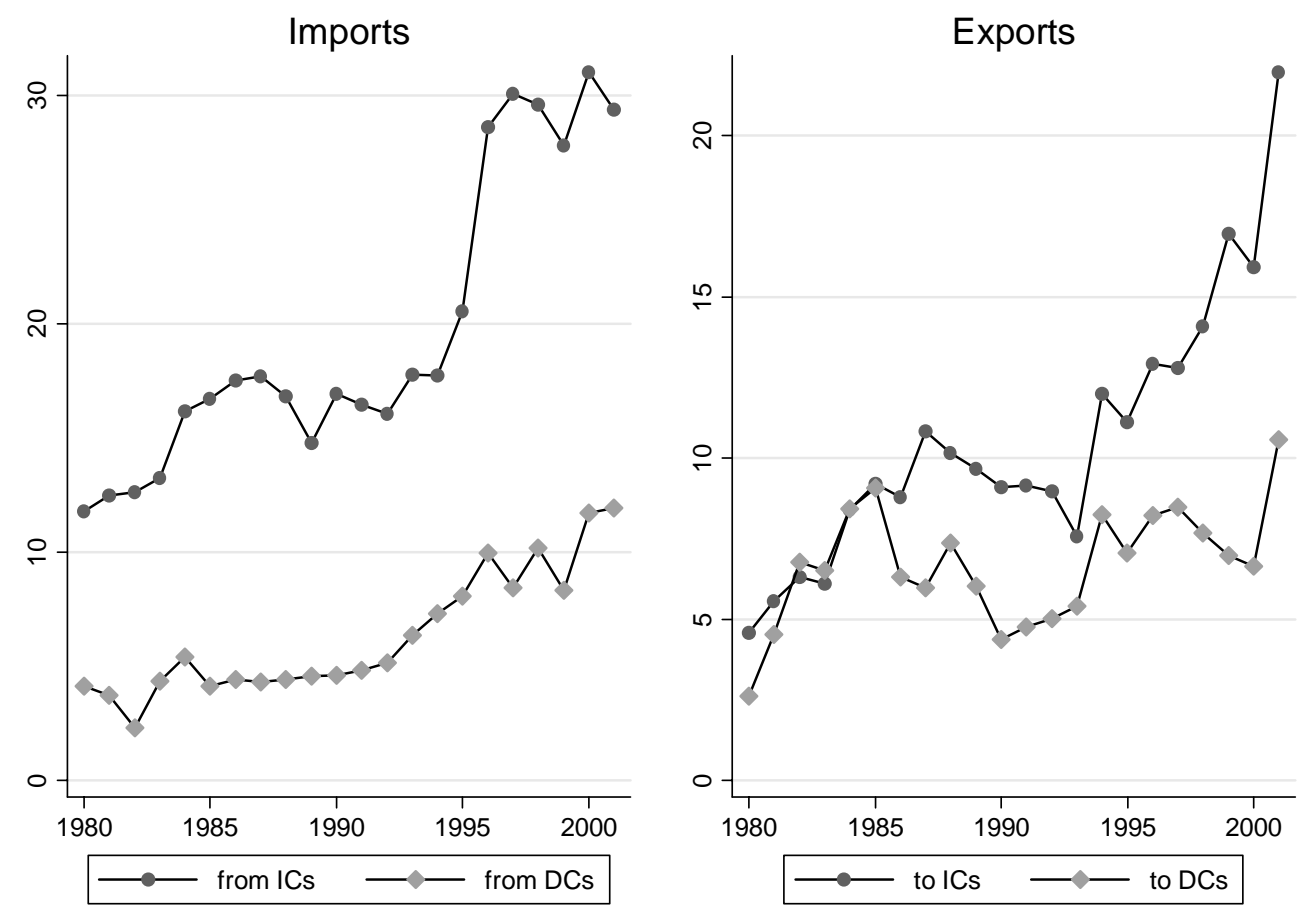

Source: Own elaborations from Annual Manufacturing Industry Statistics and Turkstat. 
Figure 2: FDI inflows

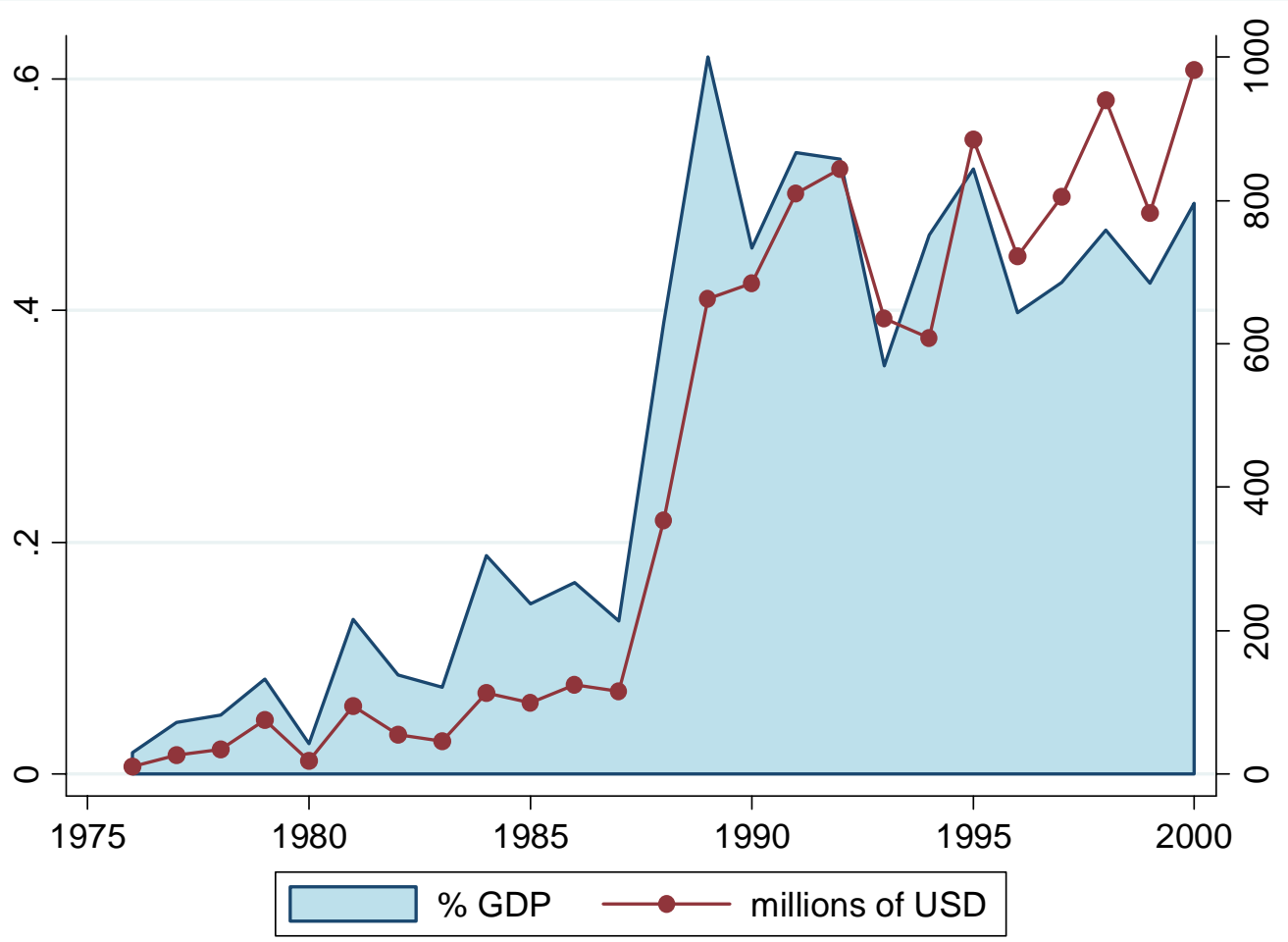

Source: FDI/TNC database, UNCTAD

Figure 3: Relative Employment and Wages in Private Sector

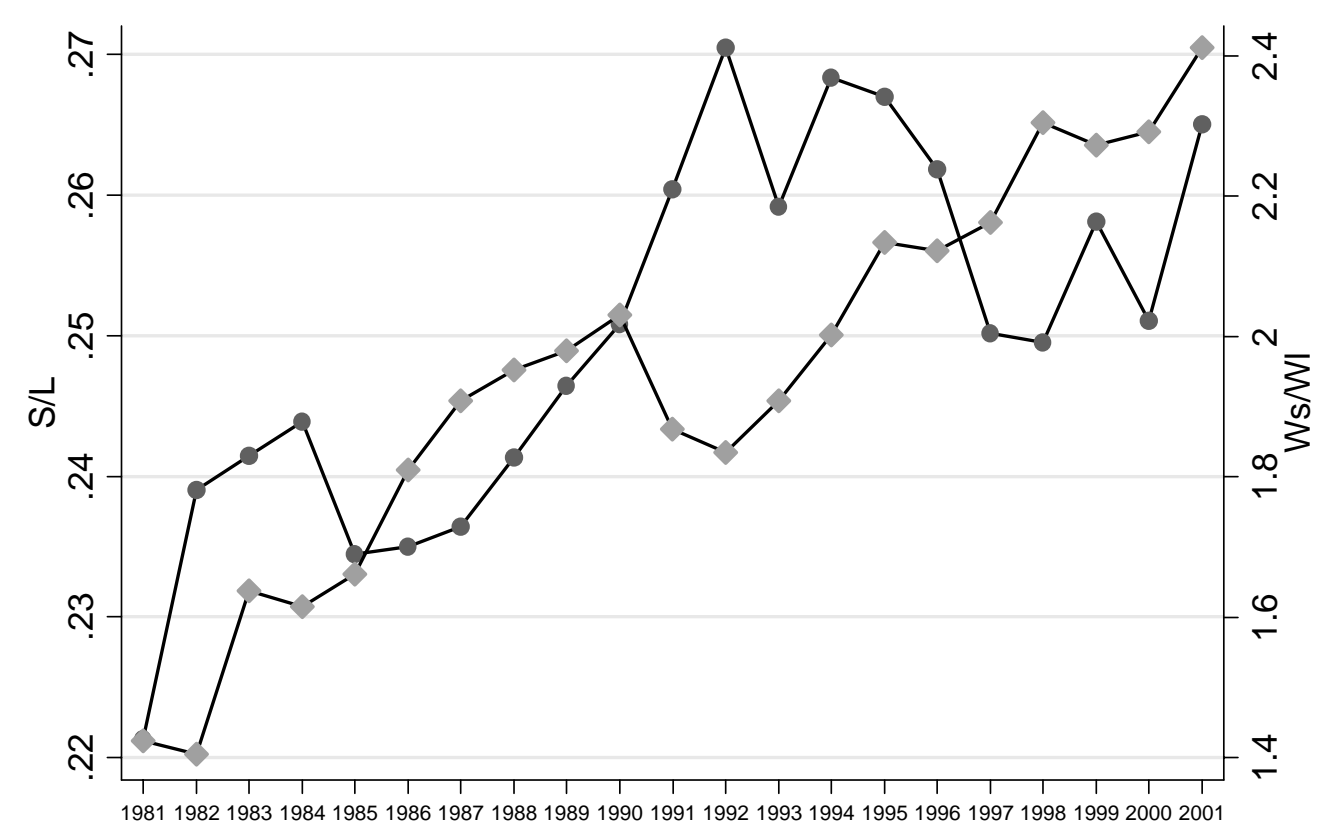

$\longrightarrow$ Relative Employment $\longrightarrow$ Relative Wages 
Source: Own elaborations from Annual Manufacturing Industry Statistics

Figure 4: Evolution of the labour cost share of skilled workers (SLCSH)

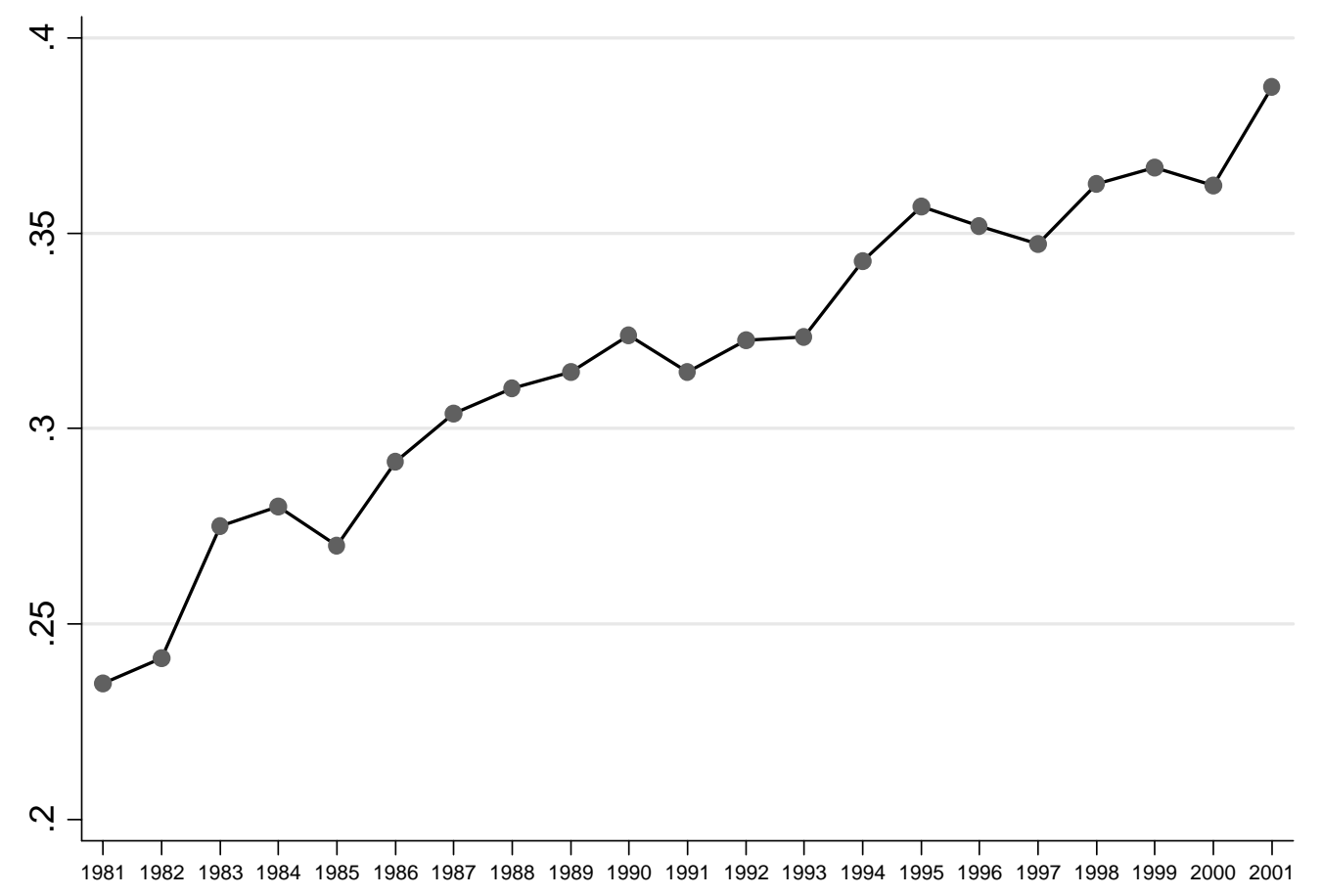

Source: Own elaborations from Annual Manufacturing Industry Statistics

Table 2: Decomposition of SLCSH changes within and between sectors

\begin{tabular}{lcccc}
\hline Years & $\begin{array}{c}\text { Within } \\
\text { component }\end{array}$ & $\begin{array}{c}\text { Between } \\
\text { component }\end{array}$ & Total Change & Within/Total \\
\hline \hline 1981-2001 & 0.135 & 0.013 & 0.148 & 0.886 \\
& & & & \\
$1980-83$ & 0.005 & 0.001 & 0.006 & 0.871 \\
$1983-88$ & 0.034 & 0.000 & 0.034 & 1.004 \\
$1988-93$ & 0.002 & 0.011 & 0.013 & 0.159 \\
$1993-94$ & 0.018 & 0.001 & 0.019 & 0.950 \\
$1994-00$ & 0.021 & -0.002 & 0.019 & 1.123 \\
$2000-01$ & 0.024 & 0.003 & 0.027 & 0.891 \\
\hline
\end{tabular}


Table 3. Dependent variable: SLCSH; GMM-SYS estimates.

\begin{tabular}{|c|c|c|c|c|}
\hline & 1 & 2 & 3 & 4 \\
\hline SLCSH (-1) & $\begin{array}{c}0.7477 * * \\
{[0.0311]}\end{array}$ & $\begin{array}{c}0.7471^{* *} \\
{[0.0310]}\end{array}$ & $\begin{array}{c}0.7471 * * \\
{[0.0311]}\end{array}$ & $\begin{array}{c}0.7471 * * \\
{[0.0311]}\end{array}$ \\
\hline $\log (\mathrm{K} / \mathrm{VA})$ & $\begin{array}{l}0.0027 * * \\
{[0.0004]}\end{array}$ & $\begin{array}{l}0.0026 * * \\
{[0.0004]}\end{array}$ & $\begin{array}{c}0.0026^{* *} \\
{[0.0004]}\end{array}$ & $\begin{array}{l}0.0026 * * \\
{[0.0004]}\end{array}$ \\
\hline $\log (\mathrm{VA})$ & $\begin{array}{l}0.0075^{* *} \\
{[0.0010]}\end{array}$ & $\begin{array}{l}0.0073^{* *} \\
{[0.0010]}\end{array}$ & $\begin{array}{c}0.0072 * * \\
{[0.0010]}\end{array}$ & $\begin{array}{l}0.0072 * * \\
{[0.0010]}\end{array}$ \\
\hline R\&D_dum & $\begin{array}{c}0.0092^{* *} \\
{[0.0016]}\end{array}$ & $\begin{array}{c}0.0091^{* *} \\
{[0.0016]}\end{array}$ & $\begin{array}{l}0.0088 * * \\
{[0.0015]}\end{array}$ & $\begin{array}{c}0.0088^{* *} \\
{[0.0015]}\end{array}$ \\
\hline fdidum & $\begin{array}{l}0.0313 * * \\
{[0.0047]}\end{array}$ & $\begin{array}{l}0.0312^{* *} \\
{[0.0047]}\end{array}$ & $\begin{array}{c}0.0307^{* *} \\
{[0.0047]}\end{array}$ & $\begin{array}{l}0.0308 * * \\
{[0.0047]}\end{array}$ \\
\hline ttrans & $\begin{array}{l}0.0118^{* *} \\
{[0.0041]}\end{array}$ & $\begin{array}{l}0.0116^{* *} \\
{[0.0041]}\end{array}$ & $\begin{array}{c}0.0109 * * \\
{[0.0041]}\end{array}$ & $\begin{array}{l}0.0107 * * \\
{[0.0041]}\end{array}$ \\
\hline expdum & & $\begin{array}{c}0.0033^{*} \\
{[0.0013]}\end{array}$ & $\begin{array}{c}0.0031^{*} \\
{[0.0013]}\end{array}$ & $\begin{array}{c}0.0031^{*} \\
{[0.0013]}\end{array}$ \\
\hline finput & & & $\begin{array}{c}0.0262^{* *} \\
{[0.0051]}\end{array}$ & \\
\hline fdcinput & & & & $\begin{array}{c}0.0361^{* *} \\
{[0.0073]}\end{array}$ \\
\hline fldcinput & & & & $\begin{array}{c}0.0129 \\
{[0.0096]}\end{array}$ \\
\hline Constant & $\begin{array}{l}-0.0072 * \\
{[0.0036]}\end{array}$ & $\begin{array}{c}-0.0058 \\
{[0.0037]}\end{array}$ & $\begin{array}{l}-0.0094 * \\
{[0.0039]}\end{array}$ & $\begin{array}{c}-0.0097^{*} \\
{[0.0039]}\end{array}$ \\
\hline Year dummies & Yes & Yes & Yes & Yes \\
\hline Observations & 88712 & 88712 & 88712 & 88712 \\
\hline N. of firms & 17462 & 17462 & 17462 & 17462 \\
\hline AR (1) & $-22.14^{* *}$ & $-22.14^{* *}$ & $-22.12 * * *$ & $-22.12 * * *$ \\
\hline AR (2) & $6.635^{* *}$ & $6.635 * *$ & $6.634^{* * *}$ & $6.634^{* * *}$ \\
\hline AR (3) & -0.408 & -0.401 & -0.403 & -0.404 \\
\hline Wald Test & $20735 * *$ & $20752 * *$ & $21302^{* *}$ & $21435 * *$ \\
\hline
\end{tabular}

Notes: robust standard errors in brackets; ${ }^{* *} \mathrm{p}<0.01,{ }^{*} \mathrm{p}<0.05$ 